\title{
Sexually Transmitted Infections Prevention across Educational Stages: Comparing Middle, High School and University Students in Portugal
}

\author{
Lúcia Ramiro ${ }^{1,2 *}$, Marta Reis ${ }^{1,2}$, Margarida Gaspar de Matos ${ }^{1,2}$, José Alves Diniz ${ }^{1,2}$, \\ Virginie Ehlinger ${ }^{3}$, Emmanuelle Godeau ${ }^{3}$ \\ ${ }^{1}$ Projeto Aventura Social, Universidade de Lisboa, Lisbon, Portugal \\ ${ }^{2}$ Centro de Malária e Outras Doenças Tropicais, Universidade Nova de Lisboa, Instituto de Higiene e Medicina \\ Tropical, Lisbon, Portugal \\ ${ }^{3}$ Service Médical du Rectorat, Research Unit on Perinatal Epidemiology and Childhood Disabilities, Adolescent \\ Health, Université Paul Sabatier, Toulouse, France \\ Email: lisramiro@sapo.pt
}

Received 3 July 2014; revised 5 August 2014; accepted 15 August 2014

Copyright (C) 2014 by authors and Scientific Research Publishing Inc.

This work is licensed under the Creative Commons Attribution International License (CC BY). http://creativecommons.org/licenses/by/4.0/

(c) $\underset{\mathrm{EY}}{\mathrm{E}}$ Open Access

\section{Abstract}

This study aimed to analyze knowledge, attitudes and sexual risk behaviors related to sexually transmitted infections and identify if sex education classes can influence students in middle, high school and university. The sample included 4751 students, mean age 16 years old, attending middle, high school and university, in Portugal. Data collection was held within the Health Behavior in School-aged Children and the Sexual and Reproductive Health in University Students surveys. The rates of students who reported having had sexual intercourse ranged from $13.2 \%$ (middle school) to $\mathbf{7 5 . 3 \%}$ (university). Among those sexually active, most reported having used condom at first sexual intercourse and not having had sexual intercourse under the influence of alcohol or drugs. Their level of knowledge regarding HIV/AIDS transmission was average and the level of positive attitudes towards HIV infected people and condoms was good. Students that reported having had sex education classes showed more accurate knowledge and fewer sexual risky behaviors. University students demonstrated more knowledge and more positive attitudes but fewer preventive sexual behaviors, which may suggest that protective behaviors are abandoned over time or that younger generations tend to protect themselves more than before. Regardless, sex education classes should be implemented before people become sexually active.

\footnotetext{
${ }^{*}$ Corresponding author.
} 


\section{Keywords}

\section{STI, Knowledge, Attitudes, Sexual Risk Behaviors, Sex Education Classes}

\section{Introduction}

According to the World Health Organization, the definition of young people considers all people aged 10 to 19 years old while the definition of youth reflects on those between 15 and 24 years old, and both comprise adolescence. Since both groups are considered priority in terms of prevention, they will both be addressed in this paper. In the modern society we live in, and more precisely in Portugal where education is compulsory until 18 and where between 30\% and 35\% of young people go to university (EACEA, 2012), sampling these groups can easily be carried out in middle, high school and university context.

Globally, around 35.3 million people live with HIV and an estimated 2.3 million people were infected in 2012. Though the number of new HIV infections has declined both among adolescents and young people (15 - 24), trends are mixed among different regions and data is still scarce (especially concerning young adolescents), so they still represent a group that has special surveillance (UNAIDS, 2013).

According to the latest Portuguese report from the national monitoring centre of sexually transmitted diseases, 2010 statistics confirmed the epidemiological pattern recorded annually since 2000, that is, there was a proportional increase in the number of cases of heterosexual transmission among the 20 - 49 years old cohort (CVEDT, 2011), which means that some were infected during adolescence or youth.

HIV prevalence is diminishing in a significant number of countries because people have less risky sexual behaviours, such as unprotected sexual intercourse, i.e. sex without condom (UNAIDS, 2010). Overall, literature claims that prevention is the best way to control STIs and condom use is generally acknowledged as the best preventive behavior regarding STIs among sexually active individuals.

Despite the reduction of HIV due to condom use, young people still are a main concern as their risk for infections is higher than in adults (UNAIDS, 2010), mainly because of their physical, emotional and cognitive immaturity.

Moreover, young people are particularly vulnerable to STIs and ensuing health problems as they lack information in relation to STIs prevention, are less prone to search for correct information or treatment (as a result of fear, introversion or inexperience) and are more prone to be involved in risky sexual practices, as they often have multiple (sequential) sex partners. Condom use at the beginning of sexual life is particularly relevant considering it is associated with its ensuing use (Shafii, Stovel, \& Davis, 2004; Shaffi, Stovel, \& Holmes, 2007). Regardless of its importance, it is seldom addressed in researches, being often replaced by condom use at last sexual intercourse. Moreover, most of the available data regarding condom use proceeds from researches whose participants' age is seldom younger than 16 years old, making it difficult to study the younger sexually active group.

Besides these broad aspects, female adolescents are more vulnerable to STIs since early sexual experience can cause trauma in vaginal tissue (UNAIDS, 2008). Thus, early sexual initiation has been pinpointed as an important indicator for sexual health (Centers for Disease Control and Prevention, 2010; UNAIDS, 2010; WHO, 2010), especially for female adolescents.

Overall, these vulnerabilities occur because young people lack information and their attitudes and skills are still not mature/developed enough in order to act preventively in a systematic way. Therefore, some strategies to reduce STIs among young people imply tailoring intervention programs that provide information and skills, as well as the support young people need to have to adopt safer sexual behavior. Such programs should be tailored to the needs they have at each specific stage of life; hence besides being built on up to date knowledge and best practices, it should emphasize greatly communication and skill-building activities.

\subsection{Sexual Behavior}

Many young people and youth engage in sexual intercourse, often with multiple (sequential) sex partners and without using condoms. In 2006, 15.4\% of middle school students and 30.6\% of high school students in Portugal reported having already had sexual intercourse and $28.8 \%$ reported having had sexual intercourse for the first 
time at 13 or sooner (Reis et al., 2011). In a US research (Eaton et al., 2008), 32.8\% of 9th graders (proxy for Portuguese middle school students-8th graders) and 43.8\% of 10th graders (proxy for Portuguese high school students - 10th graders) reported having had sexual intercourse. Overall, $7.1 \%$ of the American students that participated in the cited research reported having had sexual intercourse for the first time before age 13 . The prevalence was higher among 9th graders (9.2\%) than 10th graders (6.9\%). Some studies also reported that early sexual activity is related to substance use in different cultures (Madkour et al., 2010).

Among those sexually active in the US, 22.5\% reported having had alcohol or drugs before last sexual intercourse (Eaton et al., 2008).

Moreover, among sexually active adolescents, only 81.3\% (Portuguese survey) and 61.5\% (US survey) reported using a condom the last time they had sexual intercourse (Reis et al., 2011; Eaton et al., 2008). As for university students (18/19 years old), according to another Portuguese research (Reis, Ramiro, \& Matos, 2009), 78.3\% reported condom use at first sexual intercourse.

In a US research (Martinez, Copen, \& Abma, 2011), 73.8\% of 15 - 19 years old American students reported condom use at first sexual intercourse, while in Brazil the prevalence for 16 - 19 years old was 65.2\% (Paiva et al., 2008).

Regarding educational stages, 9th graders American students used a condom less frequently (69.3\%) than 10th graders (66.1\%) (Eaton et al., 2008). In the Portuguese research, middle school students (8th grade) also reported having used a condom during last sexual intercourse less frequently (80.2\%) than high school students (81.6\%). This shows that there is still a significant number of adolescents who do not use condom. Thus, young people engage in sexual behaviors that place them at risk for acquiring STIs, including HIV.

\subsection{Knowledge and Attitudes}

According to literature, improving knowledge on safe sex can motivate young people and youth's preventive attitudes and behaviors (Synovitz et al., 2002; Thompson et al., 1999). Therefore, increasing knowledge related to HIV prevention and positive attitudes about people living with HIV as well as increasing positive attitudes towards condom use are important aims of sexual and reproductive health.

Nevertheless, the Information Motivation Behavior Skills Model (IMB) claims that information is not enough (Fisher \& Fisher, 1993). It is also necessary to stimulate people's motivation (which includes attitudes, behavioral intentions and subjective norms) and their behavioral skills so as to expect a change in their attitude and consequently in their sexual behavior.

\subsection{Sex Education}

Since young people and youth spend a considerable amount of time in school and in university, and these are institutions where human and material resources for education exist, school education is the most effective way to improve their knowledge, attitudes and skills to protect themselves. As a result, sex education at school is crucial to the prevention of risky sexual behaviors.

A research carried out by Kirby, Laris and Rolleri (2007) studied the efficacy of HIV and sex education programs, mainly in school context. This study confirmed that many programs succeeded in postponing sex initiation, increasing condom use, enhancing knowledge regarding HIV infection, improving adolescents' understanding of attitudes about people living with HIV, and increasing condom efficacy, among others.

Sex education is compulsory in Portugal. It has been compulsory in elementary and middle school since 1986 and in high school since 2010. The Portuguese Ministry of Education published a conceptual framework and guidelines for sex education in 2000. Accordingly, sex education is integrated in a health education context that should be provided in a non-disciplinary curriculum area as well as cross-sectionally in all school subjects that contemplate sex education matters. In addition, schools should create an office to provide support to students, at an individual level. Nevertheless, not all schools have implemented the guidelines yet. Besides, in 2010, the non-disciplinary area was removed from elementary and middle school curricula, decreasing opportunities to implement sex education at school.

The goals of this article are to 1) analyze knowledge, attitudes and sexual risk behaviors related to sexually transmitted infections, and 2) identify to which degree sex education classes can influence knowledge, attitudes and sexual behaviors in Portuguese middle, high school and university students. 


\section{Method}

\subsection{Study 1: Health Behavior in School-Aged Children (HBSC)}

The Health Behavior in School-aged Children (HBSC) is a World Health Organization (WHO) collaborative cross-national study (Currie et al., 2004; Matos et al., 2011a) carried out every 4 years simultaneously in 43 countries or regions of Europe and North America in order to study school-aged behavior regarding health and risk behaviors in adolescence. Portugal is part of this group since 1996 (Currie et al., 2000).

\subsection{Study 2: Sexual and Reproductive Health in University Students (HBSC/SRHUS)}

The Sexual and Reproductive Health in University Students (HBSC/SRHUS) is a Portuguese extension of the HBSC study. It is a nationwide study that assesses HIV/AIDS-related knowledge, attitudes, and practices among the population aged 18 - 35 years old (Matos et al., 2011a).

\section{Sample}

Data were collected through two self-administered questionnaires, one from the Portuguese version of the Health Behavior in School-aged Children (HBSC) of 2010, and the other from the Sexual and Reproductive Health in University Students (HBSC/SRHUS), both nationwide surveys conducted in Portugal for the Ministry of Portuguese Health and for the National Coordination for HIV/AIDS Infection.

\subsection{Study 1}

The 2010 study provides national representative data of 5050 Portuguese adolescents, randomly chosen from those attending 6th grade, 8th grade (middle school) and 10th grade (high school) during the 2009/2010 academic year. The sample included $52.3 \%$ girls and $47.7 \%$ males, whose mean age was 14.0 years (standard deviation 1.9). The majority of adolescents was of Portuguese nationality (94.4\%), 30.8\% attended the 6th grade, $31.6 \%$ attended the 8th grade and $37.6 \%$ attended the 10 th grade. This study used a subset of 8 th $(n=1594)$ and 10th graders $(\mathrm{n}=1900)$ to represent middle school and high school educational stages, respectively. The majority was female (middle school, 51.0\%; high school, 55.7\%), Portuguese ( $\mathrm{n}=94.1 \%$ and $94.3 \%$, respectively) and their mean ages were respectively 13.8 and 15.9 (standard deviation .8 for both) (see Table 1).

Table 1. Socio demographic characteristics and sex education of total sample and subsets.

\begin{tabular}{|c|c|c|c|c|c|c|c|c|}
\hline & \multicolumn{2}{|c|}{$\begin{array}{l}\text { Middle school students } \\
\qquad(\mathrm{N}=1594)\end{array}$} & \multicolumn{2}{|c|}{$\begin{array}{l}\text { High school students } \\
\qquad(\mathrm{N}=1900)\end{array}$} & \multicolumn{2}{|c|}{$\begin{array}{l}\text { University students } \\
\text { (N = 1257) }\end{array}$} & \multicolumn{2}{|c|}{$\begin{array}{c}\text { Total }^{1} \\
(\mathrm{~N}=4751)\end{array}$} \\
\hline & $\mathrm{N}$ & $\%$ & $\mathrm{~N}$ & $\%$ & $\mathrm{~N}$ & $\%$ & $\mathrm{~N}$ & $\%$ \\
\hline \multicolumn{9}{|l|}{ Gender $(N=4751)$} \\
\hline Male & 781 & 49.0 & 841 & 44.3 & 371 & 29.5 & 1993 & 41.9 \\
\hline Female & 813 & 51.0 & 1059 & 55.7 & 886 & 70.5 & 2758 & 58.1 \\
\hline \multicolumn{9}{|l|}{ Nationality ( $N=4595)$} \\
\hline Portuguese & 1429 & 94.1 & 1716 & 94.3 & 1235 & 98.2 & 4380 & 95.3 \\
\hline Other & 89 & 5.9 & 104 & 5.7 & 22 & 1.8 & 215 & 4.7 \\
\hline \multicolumn{9}{|c|}{ Sex education classes $(\mathrm{SEC})(\mathrm{N}=4392)$} \\
\hline Having had SEC & 827 & 58.4 & 1254 & 72.1 & 745 & 60.3 & 2826 & 64.3 \\
\hline \multirow[t]{2}{*}{ Not having had SEC } & 589 & 41.6 & 486 & 27.9 & 491 & 39.7 & 1566 & 35.7 \\
\hline & M & SD & M & SD & M & SD & M & SD \\
\hline Age $(N=4751)$ & 13.8 & .8 & 15.9 & .8 & 19.8 & 2.9 & 16.2 & 2.8 \\
\hline
\end{tabular}

Note: ${ }^{1}$ The total numbers differ considering that some subjects have not replied to some variables. 


\subsection{Study 2}

The study provides national representative data of 3278 Portuguese university students, randomly chosen from those attending any graduation degree in university during the 2009/2010 academic year. The sample included $69.7 \%$ young women and $30.3 \%$ young men, (in similarity with national distribution of genders in Portuguese university), whose mean age was 21.0 years old (standard deviation 3.0). The majority of students were Portuguese (97.3\%), single (95.5\%), catholic (71.9\%) and heterosexual (96.4\%).

This study used a subset of 1st year university students $(n=1257)$ only to represent university educational stage and to maintain the time span as close as possible to the other selected groups (8th and 10th grade) to allow comparisons. The majority was female $(70.5 \%)$, Portuguese $(n=98.2 \%)$ and mean age was 19.8 (standard deviation 2.9) (see Table 1).

\subsection{Procedure (Study 1 and 2)}

The procedures followed for school and university students were similar. Data were collected through a selfadministered questionnaire. In Study 1, data were collected from the Portuguese sample of the Health Behavior in School-aged Children (HBSC), and all procedures were followed according to the international research protocol (Currie et al., 2004). Study 2-the Sexual and Reproductive Health in University Students (HBSC/ SRHUS) - is an extension of the HBSC, following the same procedures.

The sampling unit used in both surveys was the class. The 139 schools/19 university colleges in the samples were randomly selected from the official national list of schools/colleges, stratified by region (North, Center, Lisbon and Tagus Valley, Alentejo and the Algarve) in the mainland. In each school/college, one class was randomly selected for each educational stage according to the international protocol. The surveys are nationwide and were conducted during 2009/2010 school year for the Ministry of Portuguese Health and for the National Coordination for HIV/AIDS Infection by the Technical University of Lisbon. These studies had the approval of a scientific committee, the National Ethics Committee and the National Commission for Data Protection and followed strictly all the guidelines for human rights protection.

\subsection{Measures}

\subsubsection{Study 1}

The HBSC questionnaire consists of three levels of questions in order to build national survey instruments: mandatory questions that every country needs to include to create the international dataset; optional packages of questions on specific topic areas from which countries can opt; and country-specific questions regarding issues of national significance. Survey questions cover a wide range of health indicators and health-related behaviors as well as the life circumstances of young people. For this paper, it was used the mandatory question regarding sexual début, the optional question about sexual intercourse under the influence of alcohol or drugs, the national question on condom use at first sexual intercourse as well as one scale related to knowledge and two scales related to attitudes.

\subsubsection{Study 2}

The HBSC/SRHUS questionnaire is a Portuguese extension of the HBSC, aimed to study specifically sexual health issues in university students; therefore, it is constituted by questions regarding its purpose. It was conducted in 2009/2010 for the first time. Survey questions cover sexual health topics only.

\subsubsection{Study 1 and 2}

In both studies, questions were validated and piloted (in HBSC at both national and international levels and in HBSC/SRHUS at national level only). Only questions related to the goals of this article are presented here.

Risky sexual behavior was measured through the following behaviors - ever had sexual intercourse (Yes/No), male condom use at first sexual intercourse (Yes/No) and having had sexual intercourse after having drunk too much alcohol or taken drugs (Yes/No). As documented in literature, having ever had sexual intercourse and having had sexual intercourse after having drunk too much alcohol or taken drugs were considered as risky behaviors, and so was not having used condom at first sexual intercourse.

Knowledge regarding HIV/AIDS transmission/prevention-Adolescents and young adults were asked to respond to nine statements about HIV/AIDS transmission/prevention (Currie et al., 2000). The Portuguese version 
of the scale was used (Matos et al., 2011b). Participants were asked to respond to nine statements: 1) "it is possible to become infected with HIV/AIDS by sharing needles"; 2) "it is possible to become infected with HIV/AIDS from coughing and sneezing"; 3) "an HIV infected pregnant woman may pass the virus to her baby"; 4) "it is possible to become infected with HIV/AIDS by hugging someone infected"; 5) "the oral contraceptive can protect against HIV/AIDS infection"; 6) "it is possible to become infected with HIV/AIDS by engaging in unprotected sexual intercourse with someone just once"; 7) "someone who looks healthy can be HIV infected"; 8) "it is possible to become infected with HIV/AIDS by sharing a glass, fork/spoon"; 9) "it is possible to become infected with HIV/AIDS by blood transfusion in a Portuguese hospital". For each statement, answering categories were $1=$ Yes, $2=$ No and $3=$ I do not know. Only responses that showed correct information were scored and so final scores ranged from 0 to 9 , with high scores suggesting more valid knowledge.

Attitudes towards HIV/AIDS infected people. Adolescents and young adults were asked to respond to five statements about attitudes towards HIV-infected people (Currie et al., 2000). The Portuguese version of the scale was used (Matos et al., 2011b). Participants were asked to respond to five statements: 1) "I wouldn't be a friend of someone if he had AIDS"; 2) "Adolescents with AIDS should be allowed to go to school"; 3) "I would sit near an infected student in classroom"; 4) "I would visit a friend if he or she had AIDS"; and 5) "HIV infected people should live apart of the rest of people”. Items were rated on a 3-point rating scale $(1=$ disagree to $3=$ agree). After recoding items 1 and 5, final scores ranged from 5 to 15, with high scores suggesting more positive attitudes.

Attitudes towards condom use. Adolescents and young adults were asked to respond to four statements that constitute a subscale of Sexual Risk Behavior Beliefs and Self Efficacy Scales (Basen-Engquist et al., 1998). The Portuguese version of the scale was used (Ramiro et al., 2009). Participants were asked to respond to four statements: 1) "It would be embarrassing to buy condoms in a store"; 2) "It would feel uncomfortable carrying condoms with me"; 3) "It would be wrong to carry a condom with me because it would mean that I am planning to have sex"; and 4) "It would feel uncomfortable to ask for condoms at health care services". Items were rated on a 3-point rating scale ( 1 = disagree to 3 = agree). After recoding all items, final scores ranged from 4 to 12 , with high scores suggesting more positive attitudes.

Sex education. Adolescents and young adults were asked if they had sex education classes at school in the last years (Yes/No). The total sample was then divided in two groups according to their answer.

\subsection{Data Analysis}

Analyses and statistical procedures were carried out in the Statistical Package for Social Sciences program (SPSS, version 22.0 for Windows). Overall, structured self-reported questionnaires were responded by the subset of middle school (8th grade) and high school (10th grade) students from the HBSC (3494 participants) and the subset of first year university students from the HBSC/SRHUS (1257 participants). The total numbers differed according to the sub-sample used (middle school, high school and university students; reporting they have had sex or not), and considering that some participants have not replied to all questions. Means, standard deviations, frequencies and other descriptive statistics were performed to characterize the sample. Risky sexual behaviors, HIV/AIDS knowledge, attitudes towards HIV-infected people and attitudes towards condoms were then compared between the students who reported having had and not having had sex education using Chi-square $\left(\chi^{2}\right)$ and ANOVA tests, Scheffe post hoc and Effect size (Cohen, 1988: 53).

\section{Results}

\subsection{Differences between Educational Stages and Risky Sexual Behaviors}

There was considerable variation by educational stages since university students $(75.3 \%)$ more often reported having had sexual intercourse than high $(29 \%)$ and middle school students $(13.2 \%)(p<.0001)$. Overall, 89.1\% of the students who already had sexual intercourse referred having used a condom at the first sexual intercourse. Again, significant variation was observed between educational stages in relation to condom use at first sexual intercourse $(p<.0001)$ with sexually active high school students referring more frequent use of the condom (94.6\%) than university ones (86.4\%). Results showed that the majority (74.7\%) of students who reported having had sexual intercourse did not have it under the effect of alcohol or drugs. Yet, university students did it more frequently (35.3\%) than middle $(16.5 \%)$ and high school students $(11.2 \%)(p<.0001)$ (see Table 2$)$. 
Table 2. Differences between educational stages and risky sexual behaviors.

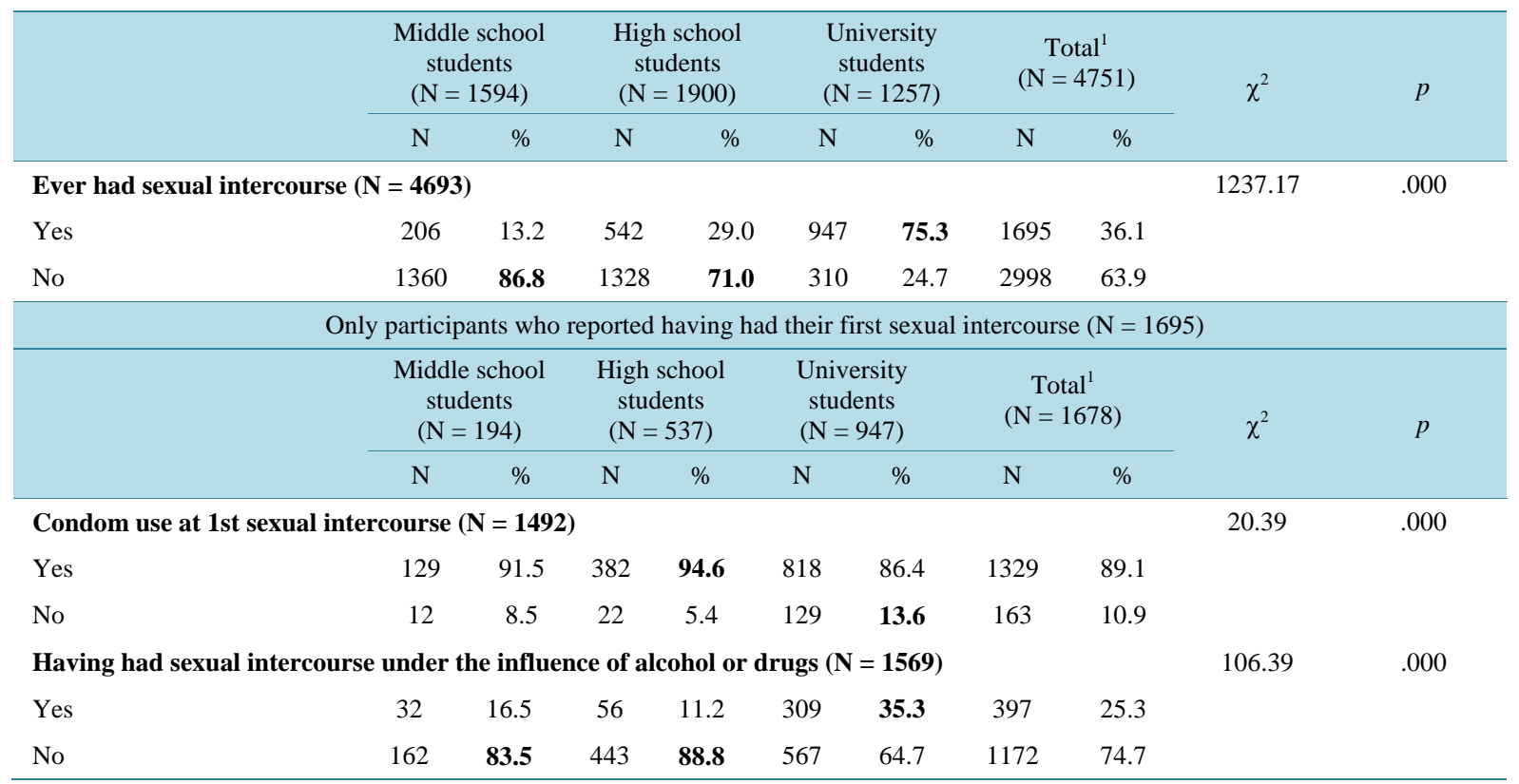

Note: ${ }^{1}$ The total numbers differ considering that some participants have not replied to some variables. In bold—values that correspond to an adjusted residual $\geq|1.9|$.

\subsection{Differences between Educational Stages and Scales of Knowledge Regarding HIV/AIDS Transmission/Prevention, Attitudes towards HIV-Infected People and Attitudes towards Condoms}

Knowledge regarding HIV/AIDS transmission/prevention: the level of general HIV/AIDS knowledge among young people was average, as indicated by a total mean score of 6.02 (SD = 2.52) out of 9 points, with university students showing significantly more knowledge $(\mathrm{M}=7.76, \mathrm{SD}=1.08)$ than high school and middle school students [(Mean = 6.21, SD = 2.27; Mean = 4.21, SD = 2.56, respectively) $(p<.0001)]$.

Attitudes towards HIV-infected people: the level of general attitudes towards HIV-infected people was good, as indicated by a total mean score of 13.35 ( $\mathrm{SD}=2.13$ ) out of 15 points, with university students showing significantly more positive attitudes (Mean $=14.60, \mathrm{SD}=1.07)$ than middle (Mean $=12.21, \mathrm{SD}=2.28)$ and high school students $($ Mean $=13.35, \mathrm{SD}=2.08 ; p<.0001)$.

Attitudes towards condoms: the level of general attitudes towards condoms was good, as indicated by a total mean score of 9.10 ( $\mathrm{SD}=2.50$ ) out of 12 points, with university students showing significantly more positive attitudes $($ Mean $=10.02, \mathrm{SD}=2.15)$ than middle $($ Mean $=8.21, \mathrm{SD}=2.55)$ and high school students $(\mathrm{M}=9.16$, $\mathrm{SD}=2.37) ; p<.0001)$.

The post hoc comparisons by the Scheffe method indicated that university students reported having more knowledge regarding HIV/AIDS transmission/prevention, more positive attitudes towards HIV-infected people and more positive attitudes towards condoms when compared with the other two educational stages (see Table 3).

\subsection{Differences between Reporting Not Having Had and Having Had Sex Education Classes, Educational Stages and Risky Sexual Behaviors}

In relation to risky sexual behaviors, high school and university students who reported having had sex education classes reported less frequently being sexually initiated $(74.9 \%$ and $27.9 \%, p<.0001)$ than those reporting not having had sex education classes (63.4\% and 20.8\%, respectively, $p<.010$ ). No statistically significant differences were observed for having had sex education and not having had sex education classes among middle school students $(p=.812)$.

Regarding condom use at first sexual intercourse, university students who reported having had sexual inter- 
Table 3. Differences between educational stages and scales of knowledge regarding HIV/AIDS transmission/prevention, attitudes towards HIV-infected people and attitudes towards condoms.

\begin{tabular}{|c|c|c|c|c|c|c|c|c|c|c|c|}
\hline & \multicolumn{2}{|c|}{$\begin{array}{l}\text { Middle } \\
\text { school } \\
\text { students }\end{array}$} & \multicolumn{2}{|c|}{$\begin{array}{l}\text { High school } \\
\text { students } \\
(\mathrm{N}=1900)\end{array}$} & \multicolumn{2}{|c|}{$\begin{array}{l}\text { University } \\
\text { students } \\
(\mathrm{N}=1257)\end{array}$} & \multicolumn{2}{|c|}{$\begin{array}{c}\text { Total }^{1} \\
(\mathrm{~N}=4751)\end{array}$} & \multirow[b]{2}{*}{$\mathrm{F}$} & \multirow[b]{2}{*}{$p$} & \multirow[b]{2}{*}{ Scheffe post hocs ${ }^{2}$} \\
\hline & M & $\mathrm{SD}$ & M & $\mathrm{SD}$ & M & SD & M & $\mathrm{SD}$ & & & \\
\hline $\begin{array}{l}\text { HIV/AIDS Knowledge } \\
\qquad(\mathrm{N}=4288)\end{array}$ & 4.2 & 2.56 & 6.2 & 2.27 & 7.8 & 1.08 & 6.0 & 2.52 & 929.413 & .000 & $\mathrm{a}<\mathrm{b}<\mathrm{c}$ \\
\hline $\begin{array}{l}\text { Attitudes towards } \\
\text { HIV-infected people } \\
(\mathrm{N}=4340)\end{array}$ & 12.2 & 2.28 & 13.4 & 2.08 & 14.6 & 1.07 & 13.4 & 2.13 & 512.684 & .000 & $\mathrm{a}<\mathrm{b}<\mathrm{c}$ \\
\hline $\begin{array}{l}\text { Attitudes towards } \\
\text { condoms }(\mathrm{N}=4300)\end{array}$ & 8.2 & 2.55 & 9.2 & 2.37 & 10.0 & 2.15 & 9.1 & 2.50 & 188.915 & .000 & $\mathrm{a}<\mathrm{b}<\mathrm{c}$ \\
\hline
\end{tabular}

Note: ${ }^{1}$ The total numbers differ considering that some participants have not replied to some variables. ${ }^{2}$ The a, b, c and $<>$ signs-represent statistically significant differences within groups for $p<.05$ by the Scheffe post hoc method.

course and having had sex education classes showed a higher prevalence of condom use (89.6\%) than those not reporting having had sex education classes $(83.0 \%)(p<.010)$. No statistically significant differences were found regarding having had sex education classes in middle $(p=.412)$ and high school students $(p=.132)$.

Concerning having had sexual intercourse under the influence of alcohol or drugs, high school students who reported having had sex education classes and having had sexual intercourse showed a higher prevalence of not having had sexual intercourse under the influence of alcohol or drugs (91.7\%) than those reporting not having had sex education (84.3\%) $(p<.050)$. No statistically significant differences were found for having had sex education classes and not having had sex education classes in middle school $(p=.629)$ and university students $(p=.449)$ (see Table 4).

\subsection{Differences between Reporting Not Having Had and Having Had Sex Education, Educational Stages and Scales of Knowledge Regarding HIV/AIDS Transmission/Prevention, Attitudes towards HIV-Infected People and Attitudes towards Condoms}

Concerning knowledge regarding HIV/AIDS transmission/prevention, students who reported having had sex education classes showed significantly more knowledge in all educational stages (middle school: Mean $=4.67$, $\mathrm{SD}=2.51$; high school: Mean $=6.53$, $\mathrm{SD}=1.99$; and university: Mean $=7.82$, $\mathrm{SD}=1.02$ ) than those reporting not having had them (Mean = 3.66, SD = 2.54; Mean = 5.47, SD = 2.65; Mean = 7.67, $\mathrm{SD}=1.18$; respectively). These differences were statistically significant in all educational stages: middle $(p<.0001)$, high school ( $p$ $<$.0001)] and university students $(p<.050)$.

Nevertheless, the effect sizes calculated only confirmed that having had sex education classes was responsible for presenting more knowledge regarding HIV/AIDS for middle and high school students. Moreover, the effect of sex education classes was small (.23; .28, respectively), according to Cohen's criteria (Cohen, 1988: 53).

Regarding attitudes towards HIV-infected people, students who reported having had sex education classes showed significantly more positive attitudes in two educational stages (middle school: Mean $=12.57$, SD $=2.22$ and high school: Mean $=13.56, \mathrm{SD}=1.93)$ than those reporting not having had them $(\mathrm{Mean}=11.80, \mathrm{SD}=2.28$; Mean $=12.85$, SD = 2.31; respectively). There was statistically significant differences for having had sex education and not having had sex education classes in middle $(p<.0001)$ and high school $(p<.0001)$ students but not in the university students group $(p=.118)$.

The effect sizes calculated confirmed that middle and high school students who reported having had sex education classes presented more positive attitudes towards HIV-infected people, though the effect of sex education was small (.20 in both groups).

As for attitudes towards condoms, only middle school students who reported having had sex education classes showed significantly more positive attitudes (Mean $=8.39$, SD $=2.46$ ) than those reporting not having had them (Mean $=7.97, \mathrm{SD}=2.65)(p<.010)$. Nevertheless, the effect size did not confirm that the difference was due to having had sex education classes (effect size $=.10$ ). As for the other educational stages, no statistically significant differences were observed in the high school and university students groups $(p=.251 ; p=.821$; respectively) (see Table 5). 
Table 4. Differences between reporting not having had and having had sex education classes, educational stages and risky sexual behaviors.

\begin{tabular}{|c|c|c|c|c|c|c|c|c|}
\hline & \multicolumn{2}{|c|}{$\begin{array}{l}\text { Not having had sex } \\
\text { education } \\
(\mathrm{N}=1566)\end{array}$} & \multicolumn{2}{|c|}{$\begin{array}{l}\text { Having had sex } \\
\text { education } \\
(\mathrm{N}=2826)\end{array}$} & \multicolumn{2}{|c|}{$\begin{array}{c}\text { Total } \\
(\mathrm{N}=4392)\end{array}$} & \multirow[b]{2}{*}{$\chi^{2}$} & \multirow[b]{2}{*}{$p$} \\
\hline & $\mathrm{N}$ & $\%$ & $\mathrm{~N}$ & $\%$ & $\mathrm{~N}$ & $\%$ & & \\
\hline \multicolumn{9}{|c|}{ Ever had sexual intercourse $(\mathrm{N}=4345)$} \\
\hline Middle school students & & & & & & & \multirow{3}{*}{.056} & \multirow{3}{*}{.812} \\
\hline Yes & 73 & 12.6 & 99 & 12.2 & 172 & 12.3 & & \\
\hline No & 507 & 87.4 & 715 & 87.8 & 1222 & 87.7 & & \\
\hline High school students & & & & & & & \multirow{3}{*}{22.42} & \multirow{3}{*}{.000} \\
\hline Yes & 176 & 36.6 & 310 & 25.1 & 486 & 28.3 & & \\
\hline No & 305 & 63.4 & 924 & 74.9 & 1229 & 71.7 & & \\
\hline University students & & & & & & & \multirow{3}{*}{8.04} & \multirow{3}{*}{.005} \\
\hline Yes & 389 & 79.2 & 537 & 72.1 & 926 & 74.9 & & \\
\hline No & 102 & 20.8 & 208 & 27.9 & 310 & 25.1 & & \\
\hline \multicolumn{9}{|c|}{ Only participants who reported having had their first sexual intercourse $(\mathrm{N}=1695)$} \\
\hline \multicolumn{9}{|c|}{ Condom use at 1st sexual intercourse $(\mathrm{N}=1419)$} \\
\hline $\begin{array}{c}\text { Middle school students } \\
\text { Yes }\end{array}$ & 46 & 93.9 & 60 & 89.6 & 106 & 91.4 & \multirow[t]{2}{*}{.67} & \multirow[t]{2}{*}{.412} \\
\hline No & 3 & 6.1 & 7 & 10.4 & 10 & 8.6 & & \\
\hline High school students & & & & & & & \multirow{3}{*}{2.27} & \multirow{3}{*}{.132} \\
\hline Yes & 126 & 93.3 & 234 & 96.7 & 360 & 95.5 & & \\
\hline No & 9 & 6.7 & 8 & 3.3 & 17 & 4.5 & & \\
\hline University students & & & & & & & \multirow{3}{*}{8.43} & \multirow{3}{*}{.004} \\
\hline Yes & 323 & 83.0 & 481 & 89.6 & 804 & 86.8 & & \\
\hline No & 66 & 17.0 & 56 & 10.4 & 122 & 13.2 & & \\
\hline \multicolumn{9}{|c|}{ Having had sexual intercourse under the influence of alcohol or drugs $(N=1493)$} \\
\hline Middle school students & & & & & & & & \multirow{3}{*}{.625} \\
\hline Yes & 9 & 12.7 & 15 & 15.3 & 24 & 14.2 & & \\
\hline No & 62 & 87.3 & 83 & 84.7 & 145 & 85.8 & & \\
\hline High school students & & & & & & & \multirow{3}{*}{5.89} & \multirow{3}{*}{.015} \\
\hline Yes & 26 & 15.7 & 25 & 8.3 & 51 & 10.9 & & \\
\hline No & 140 & 84.3 & 275 & 91.7 & 415 & 89.1 & & \\
\hline University students & & & & & & & \multirow{3}{*}{.57} & \multirow{3}{*}{.449} \\
\hline Yes & 131 & 36.9 & 173 & 34.4 & 304 & 35.4 & & \\
\hline No & 224 & 63.1 & 330 & 65.6 & 554 & 64.6 & & \\
\hline
\end{tabular}

Note: ${ }^{1}$ The total numbers differ considering that some participants have not replied to some variables. In bold—values that correspond to an adjusted residual $\geq|1.9|$.

Table 5. Differences between reporting not having had and having had sex education classes, educational stages and scales of knowledge regarding HIV/AIDS transmission/prevention, attitudes towards HIV-infected people and attitudes towards condoms.

\begin{tabular}{|c|c|c|c|c|c|c|c|c|c|}
\hline & \multicolumn{2}{|c|}{$\begin{array}{l}\text { Not having had } \\
\text { sex education } \\
(\mathrm{N}=1566)\end{array}$} & \multicolumn{2}{|c|}{$\begin{array}{l}\text { Having had sex } \\
\text { education } \\
(\mathrm{N}=2826)\end{array}$} & \multicolumn{2}{|c|}{$\begin{array}{c}\text { Total }^{1} \\
(\mathrm{~N}=4392)\end{array}$} & \multirow[b]{2}{*}{$\mathrm{F}$} & \multirow[b]{2}{*}{$p$} & \multirow[b]{2}{*}{ Effect size $(d)^{2}$} \\
\hline & M & SD & M & SD & M & SD & & & \\
\hline \multicolumn{10}{|c|}{ HIV/AIDS knowledge $(\mathrm{N}=4186)$} \\
\hline Middle school students & 3.7 & 2.54 & 4.7 & 2.51 & 4.3 & 2.57 & $51.051^{*}$ & .000 & .23 \\
\hline High school students & 5.5 & 2.65 & 6.5 & 1.99 & 6.2 & 2.25 & $78.465^{*}$ & .000 & .28 \\
\hline University students & 7.7 & 1.18 & 7.8 & 1.02 & 7.8 & 1.09 & 5.590 & .018 & .07 \\
\hline \multicolumn{10}{|c|}{ Attitudes towards HIV-infected people $(\mathrm{N}=4262)$} \\
\hline Middle school students & 11.8 & 2.28 & 12.6 & 2.22 & 12.3 & 2.27 & 38.338 & .000 & .20 \\
\hline High school students & 12.9 & 2.31 & 13.6 & 1.93 & 13.4 & 2.07 & 40.630 & .000 & .20 \\
\hline University students & 14.6 & 1.13 & 14.7 & .97 & 14.6 & 1.03 & 2.445 & .118 & .05 \\
\hline \multicolumn{10}{|c|}{ Attitudes towards condoms $(\mathrm{N}=4243)$} \\
\hline Middle school students & 8.0 & 2.65 & 8.4 & 2.46 & 8.2 & 2.55 & 8.793 & .003 & .10 \\
\hline High school students & 9.1 & 2.35 & 9.2 & 2.36 & 9.2 & 2.36 & 1.319 & .251 & .04 \\
\hline University students & 10.0 & 2.25 & 10.0 & 2.08 & 10.0 & 2.15 & .051 & .821 & .01 \\
\hline
\end{tabular}

Note: ${ }^{1}$ The total numbers differ considering that some participants have not replied to some variables; ${ }^{2}$ The Effect Sizes estimators are reported in 


\section{Discussion/Conclusion}

Overall, sexual health is a matter that calls for intervention. Since AIDS has been identified as pandemic, nations, including the Portuguese, have committed to promote safer sexual health. The implementation of sex education has shown to be an important key to the solution for this problem (Ramiro \& Matos, 2008). Our analyses suggest that overall Portuguese youth have safe sexual behaviors. Nonetheless, there are a minor but relevant number of individuals that referred having some risky behaviors, therefore putting themselves at risk.

As expected, there was significant variation by educational stages: Portuguese middle and high school students reported less being sexually active and having had sexual intercourse under the influence of alcohol or drugs than university students. These results are in the range of those found in a similar nationwide US research conducted at the same time, the Youth Risk Behavior Surveillance, with 64\% of young Americans (10 - 24 years old) referring not being sexually active (Centers for Disease Control and Prevention, 2010). For our youngest age group, they compare as well with the results of the last HBSC survey cycle, where $74 \%$ (HBSC average) of 15-year-old reported not having had first sexual intercourse (Currie et al., 2012).

It is broadly accepted that condoms provide the best protection from STIs, including HIV but they must be used without fail and correctly in every act of intercourse (DGS, 2004). The important contribution that sex education can have in increasing condom use is also acknowledged (Kirby et al., 2007; Mueller, Gavin, \& Kulkarni, 2008), as well as in preventing other risky sexual behaviors such as sexual intercourse associated to alcohol or drugs (Madkour et al., 2010).

The rates of condom use during first sexual intercourse were very high among Portuguese middle (91.5\%), high school (94.6\%) and university (86.4\%) students. Yet, the rate decreased from high school to university, which may suggest that protective behaviors are abandoned over time. Alternatively it could suggest that younger generations tend to protect themselves more than before. These findings are similar to those of a research conducted in a geographically and culturally similar country, where 96.2\% of 13/14-year-old Spanish middle school students and 97.8\% of 15/16-year-old Spanish high school students reported having used condom during first sexual intercourse (Teva, Bermúdez, \& Buela-Casal, 2009).

Results showed that the majority (middle school—83.5\%, high school—88.8\%, university-64.7\%) did not have sexual intercourse under the effect of alcohol and drugs. Nevertheless, $35.3 \%$, which is a relevant percentage of Portuguese university students, reported such a situation. The findings related to Portuguese young people are in line in the YRSB research (Centers for Disease Control and Prevention, 2010), with 78.4\% referring not having had sexual intercourse under the effect of alcohol and drugs. It is imperative to implement successfully demonstrated strategies into present prevention programs besides continuing to find new ways to protect young people and youth and enhance their skills to protect themselves from negative outcomes such as unwanted sexual activity, pregnancy or STI/HIV infections.

Because the rates of HIV/AIDS in young people and youth have always been a major concern (UNAIDS, 2010), raising knowledge about HIV transmission routes and prevention, and promoting positive attitudes towards HIV infected people and condom use have equally been identified as sex education prerogatives (Kirby et al., 2007). Our paper suggests that Portuguese young people have reasonable knowledge regarding HIV/AIDS transmission/prevention and show positive attitudes towards HIV infected people.

University students demonstrated significantly more knowledge and more positive/tolerant attitudes both towards infected people and condoms. Overall, in most comparable studies the knowledge level about HIV/AIDS prevention was considered moderate/moderately high (Bana et al., 2010; Tavoosi et al., 2004), which is similar to this sample. As for attitudes towards HIV infected people, studies with societies culturally similar to the Portuguese were unavailable so it is advisable that investigation is carried out on this subject. In relation to attitudes towards condom use, the Portuguese results were in line with those of the HBSC Scottish sample, where a proactive attitude towards condoms was observed (Kirby, Van der Sluijs, \& Currie, 2010).

Students who reported having had sex education classes reported less frequently having ever had sexual intercourse (high school and university students), showed a higher prevalence of condom use at first sexual intercourse (university students) and reported more frequently not having sexual intercourse under the influence of alcohol or drugs (high school students); therefore exhibiting safer sexual behaviors.

Considering condom use at first sexual intercourse is associated with ensuing use, the prevalence of condom use at last intercourse is probably as well lower among university compared to younger educational stages too. 
Still, sex education classes showed a positive influence in condom use among university students, suggesting its importance. Nevertheless, its effects are greater when implemented before people become sexually active, that's probably why middle and high school students' prevalence of condom use is higher. The fact that sex education classes weren't associated to condom use in younger students is probably due to difficulty in assessing behavior change within a period of time smaller than ten years.

Students in the lower educational stages (middle and high school students) who reported having had sex education classes showed significantly more knowledge regarding HIV/AIDS transmission/prevention and more positive attitudes towards HIV-infected people, thus documenting the importance of sex education, similarly to the research carried out by Kirby et al. (2007). Since sex education is still in the process of being implemented in Portugal, it is acceptable to consider that university students have had less opportunity to have sex education classes and that when they reported them, the sex education they have had probably was still not as systematic and effective as nowadays. Another important aspect is that none of the educational stages showed more positive attitudes towards condoms, where sex education classes haven't made a difference, yet. This also seems acceptable since demonstrating a positive attitude towards condom use, and even more using them is much more demanding than demonstrating a positive attitude towards HIV-infected people. Besides, improving one's attitudes towards condom use is much more specific and behavior-related than changing attitudes towards HIV-infected people, where there's a big probability one doesn't know anyone with that condition.

Our analysis suggested that sex education in school can promote safer sexual behaviors, although there is still a minor but relevant number of individuals that engaged in risky behaviors, which can have negative consequences not only regarding public health but also individual matters.

Most of the programs that aim to change young people's sexual risky behaviors directly target young people. However, teachers, parents and peers can also be considered as important agents in youth change. Generally, these programs are tailored to be implemented in school context. Nevertheless, sex education in universities, the place where young people spend the stage of life where they are more sexually active is seldom addressed and statistics show how relevant this issue is. The Health Offices for Information and Students' Support that exist in most schools should be extended to Universities. These offices should include partnerships with relevant structures, such as health centers, hospitals and associations related to sexuality, in order to raise awareness, train skills and provide individual support related to sexuality matters.

It is fundamental to understand that primary prevention is the one that aims to promote safe sexual behaviors since it develops cognitive and behavioral skills that are fundamental to promoting and maintaining positive changes. Sex education requires that the agents involved, whether directly or indirectly (especially family, schools and universities) gain awareness of their importance in young people's development.

It is recommended that sexual education continues to be compulsory and prioritized in Portuguese schools. Therefore, the non-disciplinary area which has been removed from elementary and middle school curricula, and which has been decreasing the opportunity to implement sex education, should be reintroduced so as to create conditions for its sustainability.

Although we performed analyses stratified by gender (due to sex ratio differences), there were no substantive differences in results; with one exception: at university educational stage, having had sex education classes is neither associated with having had sexual intercourse nor with having used condom at first sexual intercourse. Overall, there were no differences in results and thus we presented combined analyses.

\section{References}

Bana, A., Bhat, V., Godlwana, X., Libazi, S., Maholwana, Y., \& Maragungana, N. (2010). Knowledge, Attitudes and Behaviours of Adolescents in Relation to STIs, Pregnancy, Contraceptive Utilization and Substance Abuse in the Mhlakulo Region, Eastern Cape. South African Family Practice, 52, 154-158. http://www.ajol.info/index.php/safp/article/view/54317

Basen-Engquist, K., Mâsse, L.C., Coyle, K., Kirby, D., Parcel, G., Banspach, S., \& Nodora, J. (1998). Sexual Risk Behavior Beliefs and Self-efficacy Scales. Handbook of Sexuality-Related Measures. Thousand Oaks: Sage, 541-544.

Centers for Disease Control and Prevention (2010). Youth Risk Behavior Surveillance-United States, 2009: Surveillance Summaries. Department of Health and Human Services, MMWR, 59. http://www.cdc.gov/mmwr/pdf/ss/ss5905.pdf

Cohen, J. (1988). Statistical Power Analysis for the Behavioral Sciences. Hillsdale, NJ: Lawrence Erlbaum.

Currie, C., Hurrelmann, K., Settertobulte, W., Smith, R., \& Todd J. (2000). Health and Health Behavior among Young People. Copenhagen: World Health Organization. 
http://www.euro.who.int/_data/assets/pdf_file/0006/119571/E67880.pdf

Currie, C., Roberts, C., Morgan, A., \& Smith, R. (2004). Young People’s Health in Context: International Report from the HBSC 2001/02 Survey. In WHO Policy Series: Health Policy for Children and Adolescents. Copenhagen: WHO Regional Office for Europe. http://www.euro.who.int/_data/assets/pdf_file/0008/110231/e82923.pdf

Currie, C., Zanotti, C., Morgan, A., Currie, D., de Looze, M., \& Roberts, C. (2012). Social Determinants of Health and Well-Being among Young People. Health Behaviour in School-Aged Children (HBSC) Study: International Report from the 2009/2010 Survey. In WHO Policy Series: Health Policy for Children and Adolescents. Copenhagen: WHO Regional Office for Europe.

http://www.euro.who.int/ data/assets/pdf file/0003/163857/Social-determinants-of-health-and-well-being-among-young -people.pdf

CVEDT-Centro de Vigilância das Doenças Sexualmente Transmissíveis. Infecção VIH/SIDA (2011). A situação em Portugal a 31 de Dezembro de 2010. [HIV/AIDS (2011). The Situation in Portugal on December 31, 2010]. Lisboa: INSA. http://www.AIDSportugal.com/Modules/WebC_Docs/GetDocument.aspx?.DocumentId=2809.

DGS—Direcção Geral de Saúde (2004). Orientações estratégicas. Plano Nacional de Saúde 2004-2010: Mais saúde para todos [Strategic Guidelines. National Health Plan 2004-2010: Better Health for All]. Lisboa: Direcção-Geral da Saúde. http://www.cm-cascais.pt/sites/default/files/anexos/gerais/planonacionaldesade_prioridades.pdf

EACEA: Education, Audiovisual and Culture Executive Agency (EACEA P9 Eurydice) (2012). Key Data on Education in Europe 2012. Brussels: Education, Audiovisual and Culture Executive Agency. http://eacea.ec.europa.eu/education/eurydice/documents/key_data_series/134en.pdf

Eaton, D., Kann, L., Kinchen, S., Shanklin, S., Ross, J., \& Hawkins, J. (2008). Youth Risk Behavior Surveillance, United States, 2007. Morbidity and Mortality Weekly Report, 57, 1-131. http://www.cdc.gov/mmwr/preview/mmwrhtml/ss5704a1.htm

Fisher, W., \& Fisher, J. (1993). Understanding and Promoting AIDS Preventive Behaviour: A Conceptual Model and Educational Tools. The Canadian Journal of Human Sexuality, 1, 99-106.

Kirby, D., Laris, B. A., \& Rolleri, L. (2007). Sex and HIV Education Programs: Their Impact on Sexual Behaviors of Young People throughout the World. Journal of Adolescent Health, 40, 206-217. http://dx.doi.org/10.1016/j.jadohealth.2006.11.143

Kirby, J., Van der Sluijs, W., \& Currie, C. (2010). HBSC Briefing Supplement 18b: Attitudes towards Condom Use among Young People. Child and Adolescent Health Research Unit, The University of Edinburgh, HBSC Briefing Paper Series.

Madkour, A., Farhat, T., Halpern, C., Godeau, E., \& Gabhainn, S. (2010). Early Adolescent Sexual Initiation as a Problem Behavior: A Comparative Study of Five Nations. Journal of Adolescent Health, 47, 389-398. http://dx.doi.org/10.1016/j.jadohealth.2010.02.008

Martinez, G., Copen, C., \& Abma, J. (2011). Teenagers in the United States: Sexual Activity, Contraceptive Use, and Childbearing, 2006-2010 National Survey of Family Growth. National Center for Health Statistics. Vital Health Statistics.

Matos, M. G., Reis, M., Ramiro, L., \& Equipa Aventura Social (2011a). Saúde Sexual e Reprodutiva dos Estudantes do Ensino Superior-Relatório do Estudo [Sexual Reproductive Health of Collegue Students—Study Report]. HBSC/SSREU, ACS/FMH/UTL/CMDT-UNL.

Matos, M.G., Simões, C. Tomé, G., Camacho, I., Ferreira, M., \& Ramiro, L. (2011b). A Saúde dos Adolescentes Portugueses-Relatório do Estudo HBSC 2010 [The Health of Portuguese Adolescents—HBSC Study Report 2010]. ACS/FMH/ UTL/CMDT-UNL.

Mueller, T. E., Gavin, L. E., \& Kulkarni, A. (2008). The Association between Sex Education and Youth's Engagement in Sexual Intercourse, Age at First Intercourse, and Birth Control Use at First Sexual Intercourse. Journal of Adolescent Health, 42, 89-96. http://dx.doi.org/10.1016/j.jadohealth.2007.08.002

Paiva, V., Calazans, G., Venturi, G., Dias, R., de População, G., \& Sexualidade e AIDS (2008). Age and Condom Use at First Sexual Intercourse of Brazilian Adolescents. Revista de Saúde Pública, 42, 45-53. http://www.ncbi.nlm.nih.gov/pubmed/18660924

Ramiro, L., \& Matos, M. G. (2008). Perceptions of Portuguese Teachers about Sex Education. Revista de Saúde Pública, 42, 684-692. http://dx.doi.org/10.1590/S0034-89102008005000036

Ramiro, L., Reis, M., Matos, M. G., Diniz, J., \& Simões, C. (2011). Educação Sexual, Conhecimentos, Crenças, Atitudes e Comportamentos nos adolescentes [Sexual Education, Knowledge, Beliefs, Attitudes and Behaviors among Adolescents]. Revista Portuguesa de Saúde Pública, 29, 11-21.

Reis, M., Ramiro, L., \& Matos, M. G. (2009). Contracepção, Parceiros Ocasionais e Consumo de Substâncias em Jovens Portugueses [Contraception, Ocasional Partners and Substance Use among Portuguese Youth]. Revista Lusófona de Ciências e Tecnologias da Saúde, 6, 206-214. http://revistas.ulusofona.pt/index.php/revistasaude/article/viewFile/1088/901

Reis, M., Ramiro, L., Matos, M. G., Diniz, J. A., \& Simões, C. (2011). Information and Attitudes about HIV/AIDS in Por- 
tuguese Adolescents: State of Art and Changes in a Four Year Period. Psicothema, 23, 260-266.

http://www.psicothema.com/pdf/3880.pdf

Shaffi, T., Stovel, K., Davis, R., \& Holmes, K. (2004). Is Condom Use Habit Forming? Condom Use at Sexual Debut and Subsequent Condom Use. Sexually Transmitted Diseases, 31, 366-372. http://dx.doi.org/10.1097/00007435-200406000-00010

Shafii, T., Stovel, K., \& Holmes, K. (2007). Association between Condom Use at Sexual Debut and Subsequent Sexual Trajectories: A Longitudinal Study Using Biomarkers. American Journal of Public Health, 97, 1090-1095. http://dx.doi.org/10.2105/AJPH.2005.068437

Synovitz, L., Herbert, E., Kelley, R., \& Carlson, G. (2002). Sexual Knowledge of College Students in a Southern State: Relationship to Sexuality Education. American Journal of Health Studies, 17, 163-172.

http://www.researchgate.net/publication/235349826_Sexual_knowledge_of_college_students_in_a_southern_state_Relati onship_to_sexuality_education

Tavoosi, A., Zaferani, A., Enzevaei, A., Tajik, P., \& Ahmadinezhad, Z. (2004). Knowledge and Attitude towards HIV/AIDS among Iranian Students. http://applications.emro.who.int/emhj/v18/03/18_3_2012_0221_0226.pdf

Teva, I., Bermúdez, M., \& Buela-Casal, G. (2009). Characteristics of Sexual Behavior in Spanish Adolescents. Spanish Journal of Psychology, 12, 471-484. http://dx.doi.org/10.1017/S1138741600001852

Thompson, C., Currie, C., Todd, J., \& Elton, R. (1999). Changes in HIV/AIDS Education, Knowledge and Attitudes among Scottish 15-16 Years Old, 1990-1994 Findings from WHO: Health Behaviour in School-Aged Children Study (HBSC). Health Education Research, 14, 357-370. http://dx.doi.org/10.1093/her/14.3.357

UNAIDS (2008). Joint United Nations Programme on HIV/AIDS. Report on the Global HIV/AIDS Epidemic. http://whqlibdoc.who.int/unAIDS/2008/9789291737116_eng.pdf

UNAIDS (2010). Global Report: UNAIDS Report on the Global AIDS Epidemic 2010. Joint United Nations Programme on HIV/AIDS. WHO Library Catalogue-in-Publication Data. http://www.unAIDS.org/globalreport/Global_report.htm

UNAIDS (2013). Global Report: UNAIDS Report on the Global AIDS Epidemic 2013. Joint United Nations Programme on HIV/AIDS. WHO Library Catalogue-in-Publication Data.

http://www.unAIDS.org/en/media/unAIDS/contentassets/documents/epidemiology/2013/gr2013/UNAIDS_Global_Report 2013_en.pdf

WHO (2010). Position Paper on Mainstreaming Adolescent Pregnancy in Efforts to Make Pregnancy Safer. Department of Making Pregnancy Safer. Geneva: WHO Document Production Services.

http://www.gfmer.ch/SRH-Course-2010/adolescent-sexual-reproductive-health/pdf/WHO-mainstreaming-adolescent-preg nancy-efforts-MPS-2010.pdf 
Scientific Research Publishing (SCIRP) is one of the largest Open Access journal publishers. It is currently publishing more than 200 open access, online, peer-reviewed journals covering a wide range of academic disciplines. SCIRP serves the worldwide academic communities and contributes to the progress and application of science with its publication.

Other selected journals from SCIRP are listed as below. Submit your manuscript to us via either submit@scirp.org or Online Submission Portal.
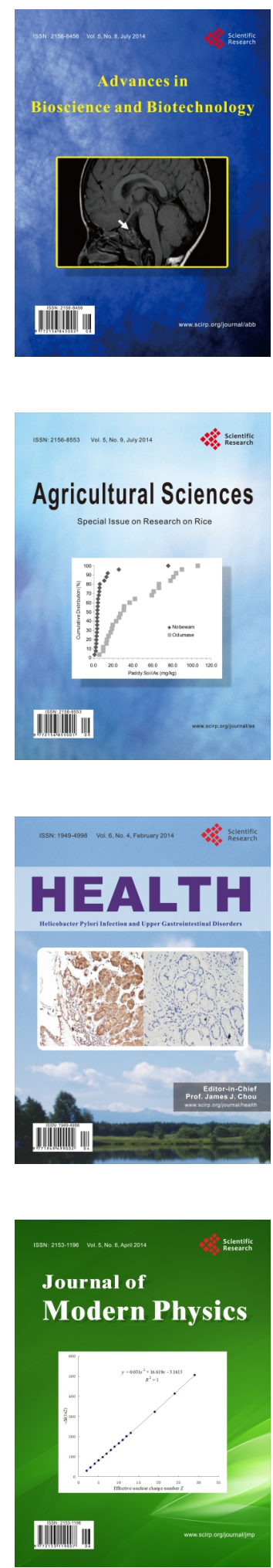
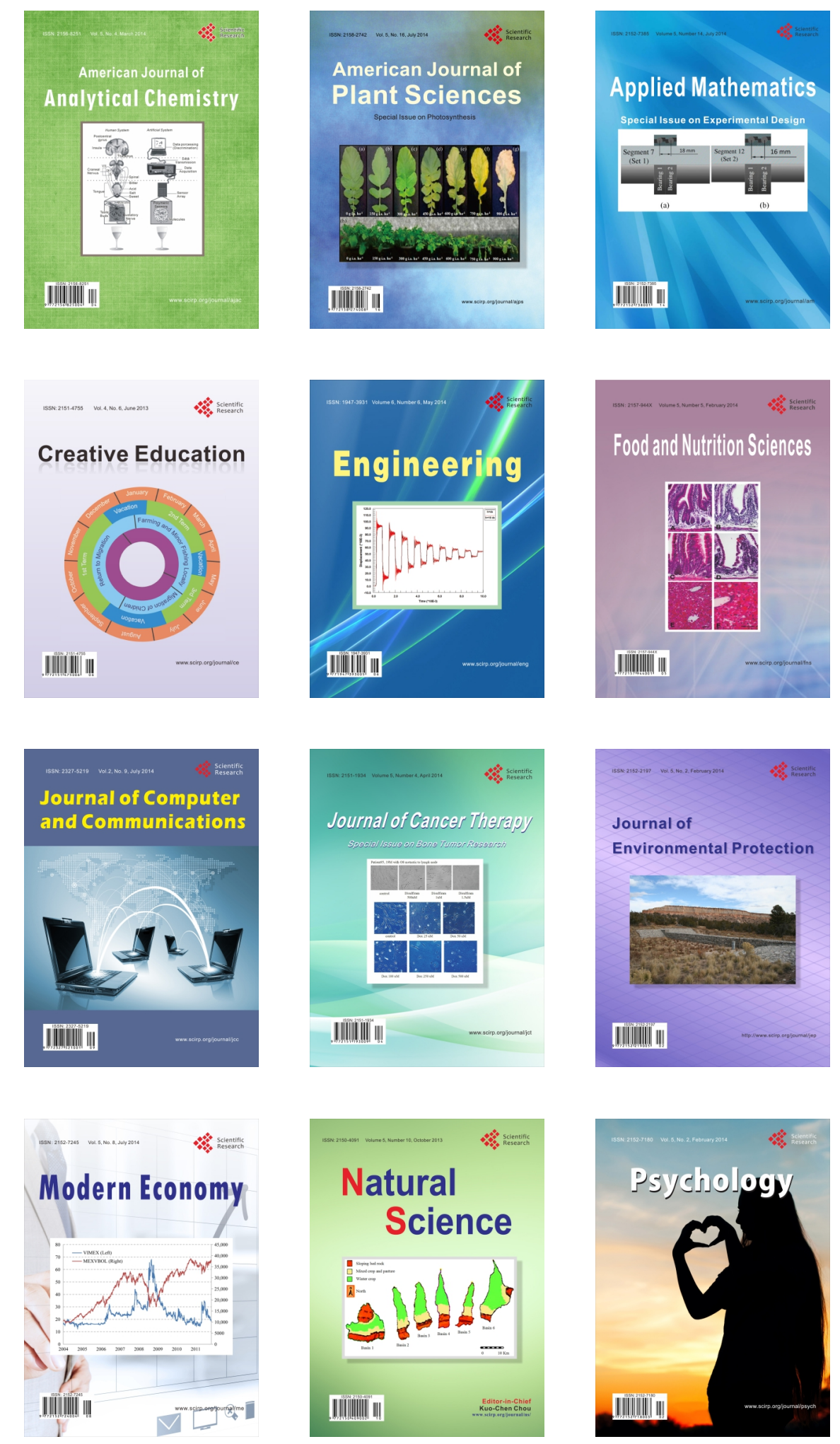